\title{
Erratum to: Ethambutol-mediated cell wall modification in recombinant Corynebacterium glutamicum increases the biotransformation rates of cyclohexanone derivatives
}

Ji-Yeong Yun · Jung-Eun Lee $\cdot$ Kyung-Mi Yang • Suekyung Cho $\cdot$ Arim Kim $\cdot$ Yong-Uk Kwon • Jin-Byung Park

Published online: 17 February 2012

(C) Springer-Verlag 2012

Erratum to: Bioprocess Biosyst Eng (2012) 35:211-216

DOI 10.1007/s00449-011-0594-z

Unfortunately, the sixth author's first name was misspelt in the original publication of the article. The correct spelling should be 'Yong-Uk Kwon'.

The online version of the original article can be found under doi:10.1007/s00449-011-0594-z.

J.-Y. Yun · J.-E. Lee · K.-M. Yang · J.-B. Park $(\bowtie)$

Department of Food Science and Engineering,

Ewha Womans University, Seoul 120-750,

Republic of Korea

e-mail: jbpark06@ewha.ac.kr

S. Cho · A. Kim - Y.-U. Kwon

Department of Chemistry and Nano Science,

Ewha Womans University, Seoul 120-750,

Republic of Korea 